IOS Press

\title{
Physicochemical properties and bioactive compounds content in encapsulated freeze-dried powders obtained from blueberry, elderberry, blackcurrant and maqui berry
}

\author{
Carolina Busso Casati, Rosa Baeza* and Virginia Sánchez \\ Facultad de Ingeniería y Ciencias Agrarias, Pontificia Universidad Católica Argentina (UCA), \\ Av. Alicia Moreau de Justo 1300 (C1107AAZ). C.A.B.A. Buenos Aires, Argentina
}

\begin{abstract}
.
BACKGROUND: Berry fruits stand out for their high contents of anthocyanins responsible for their red-purple color. The region of Patagonia, Argentina, is a significant cultivar region of these fruits. Due to berries' very short shelf-life, it is interesting the development of dehydrated products that can be stored at room temperature and still be a source of bioactive components and natural colorants.

OBJECTIVE: The objective of this work was to evaluate the effect of freeze-drying process and storage at $38^{\circ} \mathrm{C}$ on the levels of bioactive compounds and color, in lyophilized products based on blueberry, blackcurrant, elderberry and maqui berry pulps from the El Bolsón area, Río Negro, Argentina.

METHODS: Fruit pulps with addition of encapsulating agents (Maltodextrin/Arabic gum) were freeze-dried and evaluated for the content of monomeric anthocyanins, total polyphenols, antioxidant capacity, color (CIELab parameters) and physical characteristics.

RESULTS: The obtained freeze-dried powders showed high levels of retention of bioactive compounds, yielding between 68.2 and $99.6 \%$ of retention of polyphenols and anthocyanins depending on the fruit. Color parameters were also stable after freeze-drying and during 60 days of storage at $38^{\circ} \mathrm{C}$.

CONCLUSIONS: The obtained stable powder ingredients based on berries from Patagonia can be used as a source of bioactive compounds and pigments.
\end{abstract}

Keywords: Anthocyanins, color, polyphenolics, berries, storage, freeze-dried powders

\section{Introduction}

The growing trend to consume healthy food generates a demand of functional foods containing bioactive compounds. Polyphenols present in fruits and vegetables, are included in this group mainly for their properties of free radical scavengers which confer antioxidant activity against cellular oxidation reactions [1-4]. In par-

\footnotetext{
*Corresponding author: Rosa Isabel Baeza, Facultad de Ingeniería y Ciencias Agrarias, Pontificia Universidad Católica Argentina (UCA), Av. Alicia Moreau de Justo 1300 (C1107AAZ). C.A.B.A. Buenos Aires, Argentina. Tel./Fax: 54114349 0200; E-mail: rosa_baeza@ uca.edu.ar.
} 
ticular, anthocyanins are compounds associated to health promoting properties such as anti-inflammatory and antimicrobial actions and also involved in reducing the risk of having heart diseases, neurodegenerative disorders and cancer [5-8].

Berry fruits such as blueberry, elderberry, cassis, cranberry, raspberry among others, have high polyphenol content compared to other foods [9]. In particular, their red-purple color is attributed to the monomeric anthocyanins present in these fruits.

In the last years in Patagonia, the southernmost region of Argentina, there has been a significant increase in the cultivars of berries, concentrating more than $70 \%$ of Argentina's total production. Given their very short shelf-life, berries' production is mainly destined to the commercialization of refrigerated or frozen fruit and the manufacturing of jam, jellies, marmalades and other products [10].

Due to the chemical nature of anthocyanins, they could present stability problems associated with factors like temperature, $\mathrm{pH}$, presence of oxygen and light [11-12]. During processing, degradation and polymerization of monomeric anthocyanins could lead to discoloration and loss of attractive color [13]. For this reason, several technologies are applied to preserve the content of anthocyanins in fruits and to produce food products and ingredients with a longer shelf life. Preservation technologies by drying such as spray or freeze-drying, may be also used for encapsulation of bioactive compounds, thus obtaining a final product comprising highly concentrated and stable compounds with preserved characteristics such as color and chemical composition [14-15]. These dehydrated ingredients have a broad range of applications including their use as source of antioxidants and natural food colorants. In order to obtain dried foods from fruits or its juices, the proportion of the encapsulant agent to fruit solids used is relevant to obtain the dehydrated systems, since fruit juices have high concentration of sugars with low $\mathrm{T}_{\mathrm{g}}$ (glass transition temperature) like sucrose and fructose.

Although spray-drying is one of the most common techniques used to microencapsulate components [16, 17], numerous studies have shown that the freeze-drying process achieves a better retention of bioactive compounds, especially in heat-sensitive components such as anthocyanins, and better conservation of antioxidant capacity [18-20]. Freeze-drying allows the long-term preservation of heat sensitive foods and other biological materials based on the phenomena of sublimation [21].

After the freeze-drying process and under storage conditions, the stability of the compounds of interest is relevant, and it is important to know their stability, and the identification of differences in the stability of the main anthocyanins [22]. Retentions of phenolic and anthocyanin contents higher than $80 \%$ after freeze-drying processes have been observed in such dissimilar sources as grape [23-24], black carrots [25] or star fruit [26].

The objective of this work was to evaluate the effect of freeze-drying process on the levels of bioactive compounds (total polyphenols, anthocyanin content), antioxidant capacity and color parameters (CIELab parameters), and study their stability during storage in powdered products obtained from berries cultivated in El Bolsón area, Río Negro, Argentina.

\section{Materials and methods}

\subsection{Samples}

Blueberry (Vaccinium corymbosum), elderberry (Sambucus nigra), blackcurrant (Ribes nigrum) and maqui berry (Aristotelia chilensis) pulps were provided by a producer from El Bolsón, Río Negro (Argentina), obtained from fruits of the same harvest year (2016), and harvested with a similar maturation degree. The pulps were obtained from fruit blanched in water $\left(80^{\circ} \mathrm{C}, 3 \mathrm{~min}\right)$ and then crushed and peeled in an industrial pulper, packed, pasteurized $\left(85^{\circ} \mathrm{C}, 15 \mathrm{~min}\right)$ for enzyme inactivation and microbial growth inhibition and frozen at $-18^{\circ} \mathrm{C}$.

\subsection{Freeze-drying and encapsulation procedure}

Pulps of blueberry (BB), blackcurrant (BC), elderberry (EB) and maqui berry (MB) were mixed with Maltodextrin $\mathrm{DE}_{10}$ and Arabic Gum $(80: 20)$ at a ratio of $20 \%$ of encapsulating agents, poured onto an aluminum 
tray and frozen at $-20^{\circ} \mathrm{C}$ during $24 \mathrm{~h}$. Then they were freeze-dried at room temperature $\left(22 \pm 3^{\circ} \mathrm{C}\right)$ in a FIC-LII-E300-CRT freeze dryer (Buenos Aires, Argentina) operated with a freezing plate and condenser at $-40^{\circ} \mathrm{C}$ and a vacuum of $100 \mu \mathrm{m} \mathrm{Hg}$ during $40 \mathrm{~h}$. The freez-dried amorphous carbohydrate matrix was milled to obtain a powder which was fractionated in sterile, hermetic flasks and stored at $-18^{\circ} \mathrm{C}$ until use.

\subsection{Storage conditions}

Freeze-dried samples were stored in darkness at $38^{\circ} \mathrm{C}$ for 60 days and, at selected times ( 15 days intervals), 2 samples were removed to take measurements. A temperature of $38^{\circ} \mathrm{C}$ was selected because it is usually recommended for accelerated shelf life studies of foods to be marketed at ambient temperature [27].

\subsection{Alcoholic extracts}

Samples of powder were reconstituted with distilled water to obtain the same ${ }^{\circ}$ Brix as the suspension of juice and carrier to be freeze dried. Reconstitution factors ( $\mathrm{g}$ water/g powder) were: 2.68 for blueberry, 2.14 for blackcurrant, 2.40 for elderberry and 1.86 for maqui berry.

5 grams of pulps or freeze-dried reconstituted samples were extracted twice in $20 \mathrm{ml}$ ethanol: $\mathrm{HCl} 0.1 \mathrm{~N}$ $(85: 15)$ [28]. The pellets with no detectable residual content of phenolics, were eliminated by centrifugation and the supernatants were mixed and utilized for measurements of total phenolics, total monomeric anthocyanins, polymeric color, total antioxidant capacity, color parameters and HPLC assay.

Results are expressed by gram of pulp or powder as indicated and taking into account their correspondent density.

\subsection{Reagents}

Maltodextrin Dextrose Equivalent 10 ( $\mathrm{MDE}_{10}$ ) from Productos de Maíz S.A., Buenos Aires, Argentina and Arabic Gum (AG) from Gelfix S.A., Buenos Aires, Argentina, were used for encapsulation of freeze-dried berry pulps. Ethanol and chlorhydric acid used as solvents for juice extraction were from Biopack, Buenos Aires, Argentina. Folin-Ciocalteu reagent was purchased from Merck KgaA Darmstadt, Germany. HPLC standard was obtained from Sigma-Aldrich, USA. Gallic acid used for phenolic standard curve was obtained from Anedra, Buenos Aires, Argentina. All chromatographic solvents were of HPLC grade and the purity of the reagents used was p.a. or similar.

\subsection{Methods}

\subsubsection{Physicochemical properties}

Total soluble solids content was evaluated in ${ }^{\circ}$ Brix with a manual refractometer Atago N2 (Tokyo, Japan), pH was measured at $25^{\circ} \mathrm{C}$ using a Hanna HI 8424 instrument (Hanna Instruments Inc., Woonsocket, RI, USA).

Water activity $\left(\mathrm{a}_{\mathrm{w}}\right)$ was determined using an electronic dew-point water activity meter Aqualab TE (Decagon Devices, Pullman, WA). The equipment was calibrated with saturated salt solutions in the water activity range of interest [29].

Viscosity was measured by means of a rotational viscometer (Brookfield DV-LVT; Brookfield Engineering Laboratories, Inc., Middleboro, MA, USA) using S-34 and S-18 spindles. The sample chamber was placed in a water jacket connected to a bath to perform the determinations at a constant temperature of $25^{\circ} \mathrm{C}$. Measurements were made at increasing rotational speeds (range $0.01-100 \mathrm{rpm}$ ) corresponding to a percentage torque ranging from 10 to 100. All determinations were made by duplicate for each sample before lyophilizing and with the reconstituted juices. 
Shear rate profiles were fitted by the Power Law as:

$$
\tau=K(D)^{n}
$$

where by: $\tau=$ shear stress $(\mathrm{mPa}), D=$ shear rate $\left(\mathrm{s}^{-1}\right), K=$ consistency coefficient $\left(\mathrm{mPa} \cdot \mathrm{s}^{\mathrm{n}}\right), n=$ flow index.

Glass transition temperatures $\left(\mathrm{T}_{\mathrm{g}}\right)$ of each freeze-dried system were determined by differential scanning calorimetry (DSC; onset values) using a TA Instrument Q2000 calorimeter (New Castle, England). The instrument was calibrated with indium $\left(156.6^{\circ} \mathrm{C}\right)$. All measurements were performed at a heating rate of $10^{\circ} \mathrm{C} / \mathrm{min}$. Hermetically sealed $40 \mu \mathrm{L}$ medium pressure pans were used, (an empty pan served as a reference). Thermograms were evaluated using Q2000 V24.11 program.

\subsubsection{Total phenolics}

Total phenolics (TP) were determined on the extracts using the Folin-Ciocalteu method according to Waterhouse [30]. Sample absorbance at $765 \mathrm{~nm}$ (PG Instruments T60U UV-Vis spectrophotometer, Leicestershire, United Kingdom) was measured, and phenolic concentrations were expressed as Gallic acid equivalent (GAE) in $\mathrm{mg} / \mathrm{l}$ or $\mathrm{g}$ of product, calculated by means of a standard curve of Gallic acid. Percent of total polyphenolic retention (\% TP) was relative to the initial polyphenol content considered as $100 \%$.

\subsubsection{Monomeric anthocyanin content, anthocyanins degradation index and polymeric color}

Total monomeric anthocyanin content (TMA) and polymeric color (PC) of juices were estimated on alcoholic extracts based on a pH-differential spectrophotometric method and a bleaching reaction with bisulfite reported by Giusti and Wrolstad [31] respectively. The maximal $\lambda$ considered was $510 \mathrm{~nm}$ for elderberry and 520 for the other berries studied. Their content was calculated as cyanidin-3-glucoside in mg/l or g of product (MW: $449.2 \mathrm{~g}$ $\mathrm{mol}^{-1}$ and $\left.\varepsilon: 26900 \mathrm{lcm}^{-1} \mathrm{~mol}^{-1}\right)$.

The anthocyanin degradation index (DI) is the rate between total and monomeric anthocyanins. It was calculated on the basis of the absorbance of the samples diluted with $\mathrm{pH} 1.0$ and 4.5 buffers (ApH1 and ApH4.5 respectively),

$$
D I=\frac{A p H 1}{(A p H 1-A p H 4.5)}
$$

Percent of total monomeric anthocyanin retention (\% TMA) was relative to the initial content considered as $100 \%$. PC was expressed in percent (\%PC) [32].

\subsubsection{Analysis of anthocyanin content by HPLC}

HPLC analyses were performed on elderberry extracts with an Agilent 1260 series HPLC system according to the method reported by Hager et al. [33]. The injection volume was $20 \mu l$ of juice extract. Separation was achieved on a reverse phase $\mathrm{C} 18 \mathrm{Gemini}{ }^{\circledR} 150 \times 4,6 \mathrm{~mm} ; 5 \mu$ column. Detection was performed using a diode array detector. Two solvents were used during the analysis. Solvent A: distilled water/formic acid (95/5) and solvent B: methanol. A constant flow of $1 \mathrm{ml} / \mathrm{min}$ was applied with a linear gradient elution profile. An external calibration curve of cyanidin-3-glucoside (cy-3G) was used for quantification, in the range 10-100 $\mu \mathrm{g} / \mathrm{ml}$. The content of total anthocyanins (TA) and the major compound (cy-3G) were analyzed by absorption at $515 \mathrm{~nm}$ and the results expressed in mg of cyanidin equivalents per liter of berries' pulp (mg cy-3G/l). The sample was prepared in duplicate and then analyzed.

\subsubsection{Color measurements}

Juices color was analyzed using a Minolta Spectrophotometer CM-600d (Konica Minolta Observer), with D65 illuminant and an observer angle of $2^{\circ}$. The calibration was done against standard white and black tiles. Color measurements were performed by applying samples of juices, extracts or powders in plastic white containers. CIELab parameters (CIE $1976 \mathrm{~L}^{*} \mathrm{a}^{*} \mathrm{~b}^{*}$ ) were $\mathrm{L}^{*}$ for lightness, $\mathrm{a}^{*}$ for redness and $\mathrm{b}^{*}$ for yellowness. Calculations of $\mathrm{h}^{\circ}$ 
$\left(\arctan \mathrm{b}^{*} / \mathrm{a}^{*}\right)$ for hue angle were made. Total color difference was calculated as $\Delta \mathrm{E}^{*}=\left[\left(\Delta \mathrm{L}^{*}\right)^{2}+\left(\Delta \mathrm{a}^{*}\right)^{2}+\right.$ $\left.\left.\Delta \mathrm{b}^{*}\right)^{2}\right]^{1 / 2}$ and expressed the magnitude of color difference between 0 and 30 days of juice storage.

\subsubsection{Antioxidant activity}

The total antioxidant activity (TAC) was evaluated using two in vitro assay: DPPH radical scavenging activity reported as mmol Trolox/ml [34] and inhibition of lipid peroxidation in brain homogenates with or without (control) the addition of berry extract. The results are expressed as TBARS pmol/mg protein and \% TBARS inhibition relative to control [35].

\subsection{Data analysis}

Replicate samples of each berry product were analyzed. All the physicochemical parameters studied were determined at least by triplicate (duplicate only for viscosity) and the average of the measurements was reported. The total phenolics, total monomeric anthocyanins from pulps and freeze-dried powders, and color parameters during storage were analyzed by one-way analysis of variance (ANOVA) test using Infostat v.2017 (Universidad Nacional de Córdoba, Argentina) [36]. Means comparisons were carried out by Student Newman-Keuls (SNK) test at $P<0.05$. Pearson's correlations between anthocyanins content and color parameters were performed $(n=15)$.

\section{Results and discussion}

\subsection{Physico-chemical and sensorial characteristics of the different berry pulps}

Table 1 shows the physico-chemical characteristics of blueberry, elderberry, blackcurrant and maqui berry pulps used to compare with freeze-dried products and raw material to produce freeze-dried products. Soluble solids range between 9.0 and $14.8^{\circ} \mathrm{Brix}$ and $\mathrm{pH}$ between 3.42 and 4.17 , which helps to prevent microbial growth in this kind of products, and water activity ranged among 0.983 and 0.989 . These parameters are in concordance with literature data [37-40], Skupien and others [41] reported in the physicochemical characterization of four highblush blueberry cultivars that soluble solids were influenced by environmental factors. The results showed that there is a concordance between higher values of soluble solids with the decrease of water activity for the different juices. Besides, is important to mention, according to bibliography references, that the characteristics of maqui berry could be more variable because it grows as a wild berry cultivar [42].

Color parameters are also associated to the sensory quality of juices, the values presented in (Table 2) describe the typical dark colors of the berries and their alcoholic extracts. Maqui berry shows the highest value of $\mathrm{L}^{*}$ ("lightness") in both products $(14.43 \pm 0.72 ; 31.83 \pm 0.20)$ while elderberry and maqui berry have the highest a* ("redness") parameters in natural juices (14.72 \pm 1.29$)$ though blackcurrant presents the highest value of a* in the alcoholic extract $(47.91 \pm 0.50), b^{*}$ parameters are similar in both samples of blueberry. The tone values $\left(\mathrm{h}^{\circ}\right.$

Table 1

Physicochemical properties of different berry juices

\begin{tabular}{lcccc}
\hline & Blueberry & Elderberry & Blackcurrant & Maqui berry \\
\hline Soluble solids $\left({ }^{\circ}\right.$ Brix $)$ & $9.0 \pm 0.1$ & $11.8 \pm 0.1$ & $14.8 \pm 0.1$ & $13.0 \pm 0.1$ \\
$\mathrm{pH}$ & $3.54 \pm 0.01$ & $3.63 \pm 0.01$ & $3.42 \pm 0.01$ & $4.17 \pm 0.01$ \\
$\mathrm{a}_{\mathrm{w}}$ & $0.989 \pm 0.001$ & $0.987 \pm 0.001$ & $0.983 \pm 0.001$ & $0.988 \pm 0.001$ \\
\hline
\end{tabular}

Values are mean \pm standard error $(n=6)$. 
hue angle) are in the same range for all juices. These low values for both $\mathrm{h}^{\circ}$ and Chroma parameters represent a purplish red color, that is a typical characteristic of different berries with high anthocyanins content [43-45]. Also, in Table 2, it can be seen that differences in color parameters are more evident in alcoholic extracts because the samples are clearer and translucent (higher values of $\mathrm{L}^{*}$ ) and only the compounds of interest for the development of colors are present due to the extraction process [46].

Table 3, shows total phenolics, total monomeric anthocyanins content and total antioxidant capacity measured by two in vitro assays: DPPH and TBARS, from all these berries. The blackcurrant stands out above other fruits for its content in TP and maqui berry for its TMA. In comparison, blueberry presented the lowest value of TP and the content of TMA was between 3 and 6 times lower than the other ones.

A variable fraction of TMA relative to TP content was obtained for each berry, being the corresponding value $30.2 \%, 16.5 \%, 11.8 \%$ and $9.7 \%$ for $\mathrm{MB}, \mathrm{EB}, \mathrm{BC}$ and $\mathrm{BB}$ respectively. The highest proportion in TMA was coincident with the highest values of red color parameter $\mathrm{a}^{*}$ of the juice.

TAC of these berries varied from 24.5 (BC) to 5.5 (BB) mmol Trolox/ml. Kevers et al. [47] showed, that the difference of both TP contents and TAC between several cultivars of blackcurrant and blueberry could be up to 2.4 times. A general good correlation between TAC and TP was observed $(R=0.98, P<0.05)$.

In a previous study including elderberry, blackcurrant, strawberry and blackberry, Jakobek and others [48] found that the highest TP contents were observed for elderberry and blackcurrant with 6361.9 and $2770.9 \mathrm{GAE} \mathrm{mg} / \mathrm{l}$ respectively. Both fruits also showed the highest TAC values 30.15 (elderberry) and 62.14 (blackcurrant) Trolox $\mu \mathrm{mol} / \mathrm{ml}$. The relative content of TMA to TP had a broad variation ranging from $66 \%$ to $16 \%$ among all the fruits studied here.

Table 2

Color parameters of juice $(\mathrm{J})$ and juice extracs $(\mathrm{JE})$

\begin{tabular}{lcccc}
\hline & Blueberry & Elderberry & Blackcurrant & Maqui berry \\
\hline $\mathrm{L}^{*}{ }_{\mathrm{J}}$ & $1.67 \pm 0.14$ & $2.06 \pm 0.20$ & $1.50 \pm 0.01$ & $14.43 \pm 0.72$ \\
$\mathrm{~L}^{*}{ }_{\mathrm{JE}}$ & $30.13 \pm 1.11$ & $22.34 \pm 0.48$ & $16.96 \pm 0.44$ & $31.83 \pm 0.20$ \\
$\mathrm{a}^{*}{ }_{\mathrm{J}}$ & $11.66 \pm 0.89$ & $14.72 \pm 1.29$ & $11.15 \pm 0.06$ & $14.63 \pm 0.60$ \\
$\mathrm{a}^{*}{ }_{\mathrm{JE}}$ & $39.20 \pm 1.04$ & $42.82 \pm 1.14$ & $47.91 \pm 0.50$ & $28.92 \pm 0.18$ \\
$\mathrm{~b}^{*}{ }_{\mathrm{J}}$ & $2.87 \pm 0.24$ & $3.55 \pm 0.35$ & $2.59 \pm 0.02$ & $4.07 \pm 0.33$ \\
$\mathrm{~b}^{*}{ }_{\mathrm{JE}}$ & $2.66 \pm 0.19$ & $11.98 \pm 0.49$ & $13.60 \pm 2.43$ & $10.06 \pm 0.16$ \\
$\mathrm{C}^{*}{ }_{\mathrm{J}}$ & $12.01 \pm 0.92$ & $15.15 \pm 1.34$ & $11.44 \pm 0.06$ & $15.19 \pm 0.65$ \\
$\mathrm{C}^{*}{ }_{\mathrm{JE}}$ & $39.29 \pm 1.03$ & $44.47 \pm 1.18$ & $49.88 \pm 0.94$ & $30.62 \pm 0.48$ \\
$\mathrm{~h}^{\circ}{ }_{\mathrm{J}}$ & $13.82 \pm 0.01$ & $13.53 \pm 0.12$ & $13.00 \pm 0.01$ & $15.32 \pm 0.72$ \\
$\mathrm{~h}^{\circ}{ }_{\mathrm{JE}}$ & $3.90 \pm 0.32$ & $15.65 \pm 0.50$ & $15.79 \pm 2.67$ & $19.18 \pm 0.24$ \\
\hline
\end{tabular}

Values are mean \pm standard error $(n=8)$.

Table 3

Content of bioactive compounds of different berries juices

\begin{tabular}{|c|c|c|c|c|c|}
\hline & & Blueberry & Elderberry & Blackcurrant & Maqui berry \\
\hline \multicolumn{2}{|c|}{ Total phenolics (mg GAE/l) } & $2970.4 \pm 178.2^{\mathrm{a}}$ & $5584.6 \pm 668.7^{\mathrm{b}}$ & $9340.3 \pm 757.3^{\mathrm{c}}$ & $5944.9 \pm 793.8^{b}$ \\
\hline \multicolumn{2}{|c|}{ Total monomeric anthocyanins (mg Cy-3G/l) } & $288.5 \pm 19.7^{\mathrm{a}}$ & $922.8 \pm 49.2^{\mathrm{b}}$ & $1222.0 \pm 50.0^{\mathrm{c}}$ & $1795.4 \pm 186.9^{\mathrm{d}}$ \\
\hline \multirow[t]{3}{*}{ Antioxidant capacity } & TAC (mmol Trolox/ml) & $5.5 \pm 0.5$ & $14.5 \pm 0.3$ & $24.5 \pm 1.0$ & $11.8 \pm 0.2$ \\
\hline & TBARS* (pmol/mg protein) & $1113 \pm 46^{*}$ & $983 \pm 18^{*}$ & $950 \pm 171^{*}$ & $978 \pm 35^{*}$ \\
\hline & $\%$ TBARS inhibition & 86.7 & 88.3 & 88.7 & 88.3 \\
\hline
\end{tabular}

Values are means \pm standard error, $n=6$. For each bioactive compound, means with different letters within the same row are significantly different $(P<0.05)$, according to SNK test.

${ }^{*}$ reference control: the content was $8395 \pm 259$ ( pmol/mg protein); $P<0.001 \mathrm{vs} \mathrm{control.}$ 
Table 4

Physicochemical properties and bioactive compounds content of different freeze-dried powders

\begin{tabular}{lccccc}
\hline & & Blueberry & Elderberry & Blackcurrant & Maqui berry \\
\hline \multicolumn{1}{c}{$\mathrm{a}_{\mathrm{w}}$} & & $0.251 \pm 0.001$ & $0.145 \pm 0.001$ & $0.090 \pm 0.001$ & $0.096 \pm 0.001$ \\
$\mathrm{~T}_{\mathrm{g}}{ }^{\circ} \mathrm{C}$ & $\mathrm{T}_{\mathrm{g} \text { onset }}$ & $40.0 \pm 0.14$ & $38.0 \pm 0.20$ & $37.8 \pm 0.74$ & $36.0 \pm 0.21$ \\
& $\mathrm{~T}_{\mathrm{g} \text { midpoint }}$ & $44.9 \pm 0.44$ & $44.9 \pm 0.22$ & $47.4 \pm 0.11$ & $43.1 \pm 0.15$ \\
& & $7.69 \pm 0.43^{\mathrm{a}}$ & $12.42 \pm 1.06^{\mathrm{b}, \mathrm{c}}$ & $14.72 \pm 0.72^{\mathrm{c}}$ & $11.21 \pm 0.89^{\mathrm{b}}$ \\
Total phenolic (mg GAE/g) & $0.743 \pm 0.05^{\mathrm{a}}$ & $1.718 \pm 0.05^{\mathrm{b}}$ & $2.546 \pm 0.08^{\mathrm{b}}$ & $4.218 \pm 0.53^{\mathrm{c}}$ \\
Total monomeric anthocyanins (mg 3G-Cy/g) & 99.64 & 84.35 & 68.23 & 95.10 \\
TP Retention (\%) & 99.61 & 71.69 & 90.14 & 94.65 \\
TMA Retention (\%) & & & & \\
\hline
\end{tabular}

Values are means \pm standard error, $n=6$. For each bioactive compound, means with different letters within the same row are significantly different $(P<0.05)$, according to SNK test.

Regarding TAC, blackcurrant is the one with the highest value, probably due to its high content of ascorbic acid [49]. Different authors reported that ascorbic acid in blackcurrants berries stimulates the antioxidant activity of polyphenolic compounds and, taking into account that anthocyanins represent for about two-thirds of antioxidant potency for these fruits, it would indicate that other very potent antioxidants were present in phenolic fraction of this berry juice $[47,50,51]$.

In recent works maqui berry showed the highest TP content (14.6 $\mathrm{g} \mathrm{GAE} \mathrm{kg}^{-1}$ fresh weight) in comparison to blueberry, blackberry, and strawberry (with nearly $6 \mathrm{~g} \mathrm{GAE} \mathrm{kg}^{-1}$ fresh weight), without the interference of vitamin $\mathrm{C}$ which has not been detected in this fruit [52]. In those works substantially higher levels of TMA in maqui berries (from 6 to $12.6 \mathrm{~g} \mathrm{~kg}^{-1}$ fresh weight) were also reported, including blackcurrant and elderberry in the comparison [53]. High correlations between TP and TAC were obtained [54]. The contribution to antioxidant capacity may vary depending on the fruit, in maqui berry the anthocyanin rich fraction has been considered as the main source, however in blueberry total phenolic content and ascorbic acid were considered the main responsible of TAC $[53,55]$.

Although blueberry pulp showed the lowest bioactive compounds values between the berries considered in present study, it showed higher levels than many other fruits reported in literature and presents an interesting anthocyanin profile, which includes it among the fruits with richest levels in these components [54].

The inhibition of lipid peroxidation using TBARS in brain homogenates (Table 3) shows values near the $90 \%$ for all the fruits. These results show that the systems studied behave as efficient antioxidants in comparison with standard polyphenolic substances and suggest that the samples analyzed not only showed a significant antioxidant capacity in vitro but also can efficiently act as chain breaking antioxidants and be involved in final process of lipid peroxidation [56].

\subsection{Physicochemical and sensorial characteristics of freeze-dried encapsulated pulps}

Table 4 presents physico-chemical properties analyzed to characterize the freeze dried powders obtained from berry pulps. The resultant freeze-dried powders showed an $a_{w}$ value in a range of 0.090-0.251 which could contribute to physico-chemical and microbiological stability of these products. The differences obtained could be due to the different composition (soluble solids and sugar profile) and viscosity of studied fruits, that can affect the process of mass transfer during dehydration.

In all cases, dehydration allowed to obtain systems rich in bioactive compounds, up to 2.5 times higher than in liquid systems, due to the concentration of these ingredients. Freeze-dried blueberry and maqui berry powders had the highest TP retention (\% TP) after treatment, 99.6 and $95.1 \%$ respectively, followed by elderberry $84.3 \%$ and blackcurrant that only retained $68.2 \%$ of bioactive compounds. About TMA retention (\%TMA), in BB, $\mathrm{BC}$ and $\mathrm{MB}$ was higher than $90 \%$, only in the case of $\mathrm{EB}$ it was observed a decrease of up to $71.6 \%$. These 
results are in concordance with literature data in freeze-dried formulated samples of pomegranate that showed a $\%$ TP retention of $90-95 \%$ [24] or a reduction of $6.4 \%-18.6 \%$ of TP and a \%TMA retention of $99.5-80.75 \%$ in freeze-dried grapes [23]. Cheng et al [57] indicated in the production of freeze-dried bayberry powder that the freeze-drying method is more beneficial for the retention of anthocyanins compared to the spray-drying method.

Other authors [32] reported that total polyphenols and monomeric anthocyanin composition in freeze-dried systems based on berries could show little differences compared to the fresh pulp depending on the type of fruit involved. These slight differences could be associated to a better extraction of the bioactive compounds in the freeze-dried matrix and with material grinding after freeze drying, that could strengthen the differences observed in $\mathrm{BC}$.

The DI (degradation index) of the powders showed little variation (1.38 BB; $1.21 \mathrm{BC} ; 1.65 \mathrm{~EB} ; 1.13 \mathrm{MB})$ compared with DI index of natural pulps (1.29 BB; 1.25 BC; $1.29 \mathrm{~EB} ; 1.15 \mathrm{MB})$ and affirms the concept that freeze-drying process is one of the best treatments to improve the retention of bioactive compounds (anthocyanins and polyphenols) compared to air-drying or spray-drying $[19,58]$.

Glass transition temperature $\left(\mathrm{T}_{\mathrm{g}}\right)$ of the freeze-dried systems was determined. $\mathrm{T}_{\mathrm{g}}$ onset and middle point values are shown in Table 4 for each fruit system, and Figure 1 shows the thermograms obtained for the different berries. The $\mathrm{T}_{\mathrm{g}}$ midpoint obtained for the freeze-dried powders varies between $43.1^{\circ} \mathrm{C}$ and $44.9^{\circ} \mathrm{C}$. The differences up to $10 \%$ in juice solids among the berries freeze-dried powders, could contribute to the variations in the $\mathrm{T}_{\mathrm{g}}$ values obtained, and also the $\mathrm{a}_{\mathrm{w}}$ obtained for the dehydrated system. Can Karaca et al [59], observed that the increase of cherry solids from $25 \%$ to $35 \%$ respect to total solids in spray-dried sour cherry powders produced with $\mathrm{MDE}_{12}$, caused the drop of $\mathrm{T}_{\mathrm{g}}$ value from $68^{\circ} \mathrm{C}$ to $40^{\circ} \mathrm{C}$. In another work, a $\mathrm{T}_{\mathrm{g}}$ value of $35.9^{\circ} \mathrm{C}$ was obtained for freeze-dried powder of cherry juice with $14 \%$ of cherry solids and $25 \% \mathrm{w} / \mathrm{w}$ of $\mathrm{MDE}_{10}$ : AG mix added $(80: 20)$ and aw $=0.10$ [60]. In freeze-dried powders obtained from bayberry juice and grape skin phenolic extract with the addition of $20 \% \mathrm{MDE}_{12}$ and $10 \%$ of $\mathrm{AG}$ respectively, $\mathrm{T}_{\mathrm{g}}$ values between $40^{\circ} \mathrm{C}$ and $50^{\circ} \mathrm{C}$ were obtained, and $\mathrm{a} \mathrm{a}_{\mathrm{w}}$ range between $0.10-0.30$ ) [15, 23]. The juice of berry fruits can contain high proportion of low molecular weight sugars and organic acids with low $\mathrm{T}_{\mathrm{g}}$ values and high hygroscopicity that affect the free-flow properties of the dehydrated powder. Fang et al [61] reported that the addition of a $\mathrm{MDE}_{10}$ fraction relative to total solids higher than 0.3 in bayberry juice, was necessary to produce a compatible matrix with bayberry solids raising the overall $\mathrm{T}_{\mathrm{g}}$ and obtaining values for the spray dried powder of up to $30^{\circ} \mathrm{C}$. $\mathrm{T}_{\mathrm{g}}$ is the transition temperature resultant of the interaction among juice encapsulated compounds and the carrying materials like maltodextrin and arabic gum. High molecular weight of both polysaccharides increases the $T_{\mathrm{g}}$ but the intensity of the interactions may vary together with the components in each juice and thus produce the slight variations observed in $\mathrm{T}_{\mathrm{g}}$ values [62].

Table 5 shows the color parameters determined for freeze-dried powders, its reconstituted products and alcoholic extracts. As the matrix formulations have carrier materials ( $\mathrm{MDE}_{10}$ and $\mathrm{AG}$ ) which are white in the dry state, it is natural that the powders have higher $\mathrm{L}^{*}$ values than fresh juices (which corresponds to the brightening of product color). The highest $\mathrm{a}^{*}$ correspond to $\mathrm{BC}$ and $\mathrm{MB}$ which are jointly related to their superior fraction of juice solids included in the matrix, with more TMA content and high \% retention compared to BB and EB. MB had the lowest value of $\mathrm{h}^{\circ}$ thus indicating the deepest red tone powder.

In most of the reconstituted products the $\mathrm{a}^{*}$ parameter tends to increase, meaning that they became visually more "red" than the fresh juice probably by the interaction with other components, because reconstituted powders have the addition of encapsulant agents. Similar trend was observed in freeze-dried chokeberrys powder [19], the value of blue-yellow parameter $b^{*}$ changed, which represented the intensity of yellow color, the greatest increase in the value of $\mathrm{b}^{*}$ parameter was in $\mathrm{BB}$, which means that more yellow component in this color spectrum, also shown in high hue angle $\mathrm{h}^{\circ}$ values (variations in color tone), a similar behavior was reported in freeze-dried blackberries powder [15]. Besides that, the BB extract shows the lowest values for $\mathrm{a}^{*}$ and $\mathrm{b}^{*}$ parameters respect to the others extracts, with a negative and small $\mathrm{h}^{\circ}$ angle reflexing a bluish red color that can be associated with lower TMA content. It is important to remark that in maqui powder and juice the aleatory presence of seeds could cause interference in their extraction results, for this reason it can be considered that the seeds may affect the 

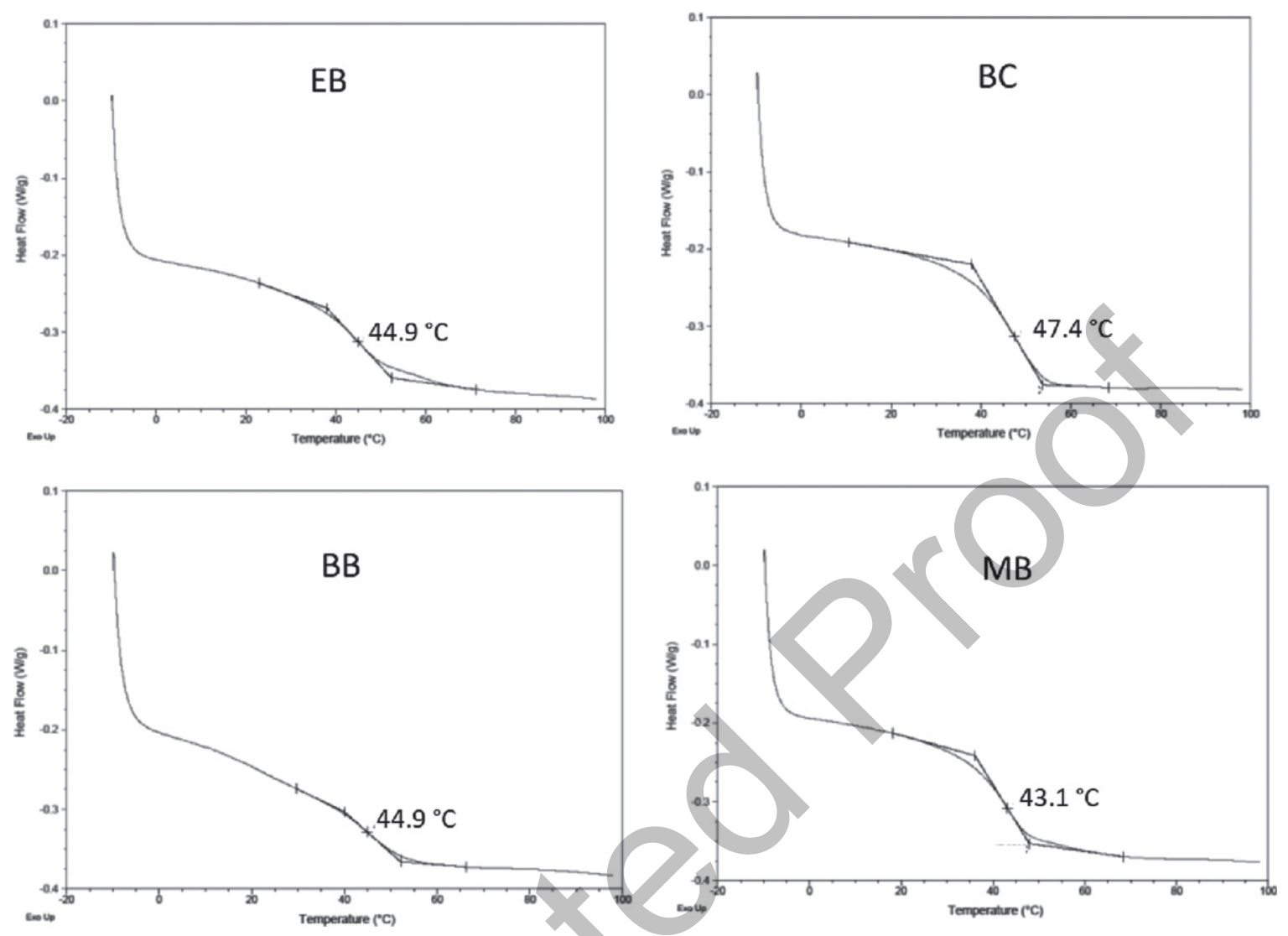

Fig. 1. DSC thermograms for freeze-dried berry powders of elderberry (EB), blackcurrant (BC), blueberry (BB) and maqui berry (MB). The value of $\mathrm{T}_{\mathrm{g} \text { midpoint }}$ is indicated in thermograms.

Table 5

Color parameters of freeze - dried powders $(\mathrm{P})$, reconstituted freeze-dried powders $(\mathrm{R})$ and its alcoholic extract $(\mathrm{Re})$

\begin{tabular}{lcccc}
\hline & Blueberry & Elderberry & Blackcurrant & Maqui berry \\
\hline $\mathrm{L}^{*} \mathrm{P}$ & $12.92 \pm 0.14$ & $10.29 \pm 0.01$ & $14.76 \pm 0.03$ & $11.96 \pm 0.04$ \\
$\mathrm{a}^{*} \mathrm{P}$ & $12.18 \pm 0.11$ & $11.68 \pm 0.04$ & $21.71 \pm 0.03$ & $17.84 \pm 0.02$ \\
$\mathrm{~b}^{*} \mathrm{P}$ & $0.97 \pm 0.02$ & $2.35 \pm 0.03$ & $3.81 \pm 0.01$ & $0.26 \pm 0.03$ \\
$\mathrm{~h}^{\circ} \mathrm{P}$ & $4.58 \pm 0.15$ & $11.34 \pm 0.15$ & $9.95 \pm 0.05$ & $0.83 \pm 0.11$ \\
$\mathrm{~L}^{*}{ }_{\mathrm{R}}$ & $16.81 \pm 0.44$ & $2.55 \pm 0.13$ & $2.34 \pm 0.04$ & $19.05 \pm 0.29$ \\
$\mathrm{a}^{*}{ }_{\mathrm{R}}$ & $23.92 \pm 0.35$ & $16.90 \pm 0.65$ & $16.44 \pm 0.19$ & $10.26 \pm 0.14$ \\
$\mathrm{~b}^{*}{ }_{\mathrm{R}}$ & $6.85 \pm 0.20$ & $4.39 \pm 0.22$ & $4.03 \pm 0.06$ & $2.44 \pm 0.04$ \\
$\mathrm{~h}^{\circ}$ & $15.75 \pm 0.26$ & $14.42 \pm 0.15$ & $13.76 \pm 0.05$ & $13.37 \pm 0.26$ \\
$\mathrm{~L}^{*} \mathrm{Re}$ & $33.90 \pm 0.17$ & $24.25 \pm 0.07$ & $19.05 \pm 0.13$ & $27.27 \pm 0.13$ \\
$\mathrm{a}^{*} \mathrm{Re}$ & $35.89 \pm 0.17$ & $46.50 \pm 0.05$ & $50.25 \pm 0.08$ & $43.92 \pm 0.18$ \\
$\mathrm{~b}^{*} \mathrm{Re}$ & $-3.87 \pm 0.01$ & $9.52 \pm 0.04$ & $8.48 \pm 0.51$ & $4.13 \pm 0.07$ \\
$\mathrm{~h}^{\circ} \mathrm{Re}$ & $-6.15 \pm 0.03$ & $11.55 \pm 0.15$ & $9.58 \pm 0.15$ & $5.37 \pm 0.07$ \\
\hline
\end{tabular}

Values are mean \pm standard error $(n=8)$. 
color changes in its alcoholic extract, showing that the major differences are in the $\mathrm{a}^{*}$ increment and $\mathrm{b}^{*}$ reduction in comparison with powder and juice extract.

The most remarkable differences described above are highlighted in (Fig. 2) that represents the total color difference $\left(\Delta \mathrm{E}^{*}\right)$ between juices pre and post freeze-drying, and also between their correspondent alcoholic extracts, where $\mathrm{BB}$ and $\mathrm{MB}$ again stand out from the others. Global color of BB juice results the most affected by the process, and it is probably related to its lowest TMA content, on the other hand in MB, the highest value calculated on its alcoholic extracts could be influenced by the removal of seeds, EB and BC have similar values in concordance with the description above.

Also, the viscosity of samples could have an influence on the brightness, $L^{*}$ parameter. Table 6 shows the values of the consistency index $(\mathrm{K})$ and the flow behavior index $(n)$ for samples of fresh pulps and reconstituted powders, which contain encapsulating agents in a proportion of $20 \%$. The shear stress profiles of juices (J) and reconstituted freeze-dried berries powders $(\mathrm{RJ})$ were well fitted to the power law and the parameters obtained were significant $\left(\mathrm{R}^{2}>0.98 ; P<0.05\right)$. In all cases it was observed that natural pulps have higher values of $\mathrm{K}$ than reconstituted juices. Comparing with fresh pulps, it was observed a decrease in $\mathrm{K}$ value in about $98 \%$ for $\mathrm{BB}$ and $90 \%$ for $\mathrm{EB}$ in reconstituted powders. In the case of $\mathrm{BC}$ and $\mathrm{MB}, \mathrm{K}$ values were $56 \%$ and $64 \%$ lower, respectively. Although the mixtures have $20 \%$ of added solids before drying, which could lead to an increase in the viscosity of the system, the final result after the freeze drying and grinding of the powder samples was a system with reduced consistency, probably due to the rupture of structures present in the fresh fruit that confer its

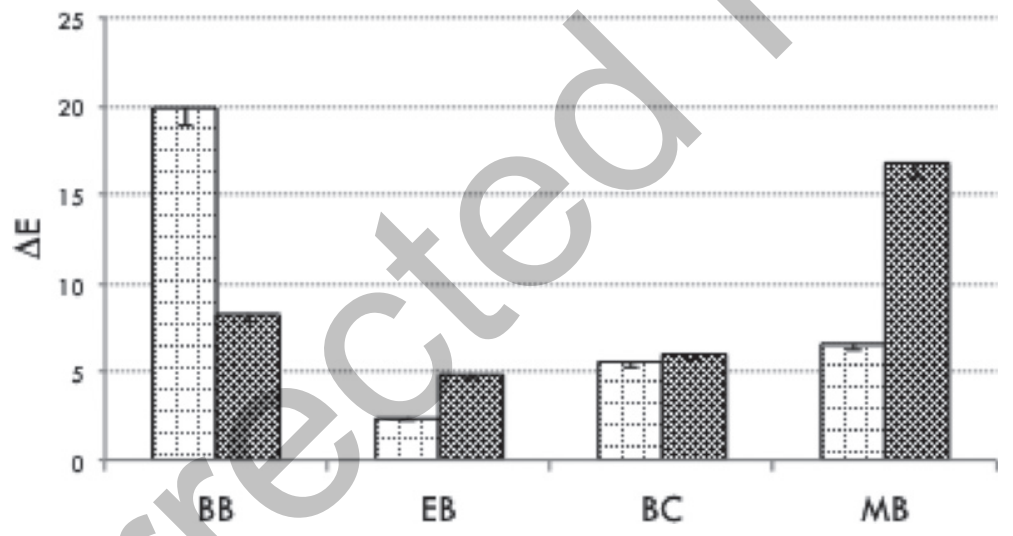

Fig. 2. Comparison of total color difference $\Delta \mathrm{E}$ between natural juice and reconstituted freeze-dried powder (䍐) and between their alcoholic extracts $(\square)$ from blueberry (BB), elderberry (EB), blackcurrant (BC) and maqui berry (MB).

Table 6

Rheological parameters: consistency index $(K)$ and flow index $(n)$ of juices $(\mathrm{J})$ and reconstituted freeze-dried berries powders $(\mathrm{RJ})$

\begin{tabular}{lcclcc}
\hline & \multicolumn{2}{c}{$K\left(\mathrm{mPa}^{\mathrm{n}} \mathrm{s}^{\mathrm{n}}\right)$} & & \multicolumn{2}{c}{$n$} \\
\cline { 2 - 3 } \cline { 5 - 6 } & $\mathrm{J}$ & $\mathrm{RJ}$ & & $\mathrm{J}$ & $\mathrm{RJ}$ \\
\hline Blueberry & $12852.6 \pm 257.0$ & $276.6 \pm 5.6$ & & $0.41 \pm 0.01$ & $0.64 \pm 0.04$ \\
Elderberry & $3438.2 \pm 69.4$ & $354.5 \pm 6.5$ & & $0.30 \pm 0.01$ & $0.67 \pm 0.01$ \\
Blackcurrant & $13921.6 \pm 180.6$ & $6100.3 \pm 48.8$ & & $0.40 \pm 0.02$ & $0.26 \pm 0.02$ \\
Maqui berry & $13429.4 \pm 201.4$ & $4815.0 \pm 38.1$ & & $0.14 \pm 0.01$ & $0.35 \pm 0.01$ \\
\hline
\end{tabular}

Values are mean \pm standard error $(n=4)$. 
high viscosity on the pulp [63]. In the case of flow behavior index $n$, both the juices and the reconstituted powders have a pseudoplastic behavior, with values of $\mathrm{n}$ between 0.14 and 0.41 for the natural juices, and between 0.26 and 0.64 for the reconstituted powders. In general, it was observed an increase in $\mathrm{n}$ for reconstituted samples, except in the case of $\mathrm{BC}$, where $\mathrm{n}$ value is lower than in the natural pulp. These results show that, in general, after the dehydration and grinding process, a lower consistency and a fluidization of the samples is observed compared to the natural juices. This aspect could have relevance when comparing the consistency between natural juices and reconstituted powders for example for industrial applications where these powder ingredients can be used in replacement of natural pulps.

\subsection{Storage effect on physico-chemical and sensorial characteristics of freeze-dried encapsulated pulps at $38^{\circ} \mathrm{C}$.}

Figure 3a shows the evolution of TMA\% retention throughout 60 days of storage at $38^{\circ} \mathrm{C}$ for the four berry powder systems. Considering the initial and final content after storage, the percent of retention was similar in all cases: 84.67 in $\mathrm{MB}, 83.43$ in $\mathrm{EB}, 84.02$ in BC and 75.79 in BB. The stability of anthocyanins was checked by HPLC for elderberry, where the major anthocyanin, cy-3G, that represented $42 \%$ of total anthocyanins was monitored at the beginning and at 60 days of storage of the powder. The percent of retention after storage was 85.9\%, and the major peak in HPLC profiles corresponding to cy-3G, remained stable. Taking into account that at zero time TA content was $931 \mathrm{mg} / \mathrm{l}$, at 60 days it maintained a value of $834.74 \mathrm{mg} / \mathrm{l}$. Sanchez et al, [60] reported TMA stability values of $90 \%$ for freeze-dried cherry juice in a $\mathrm{MDE}_{10} / \mathrm{AG}$ matrix stored at similar conditions. Others authors [32] found little variation on DI during storage for various freeze dried berries. Garzón and Worlstad [64] indicated that chemical structure of anthocyanin (glicosidic and acilation structure) were the main factor that affected their stability and found a direct relationship between water activity increase and DI. Besides, the stability of anthocyanins and polyphenols encapsulated is dependent on physical changes of the amorphous glassy matrix. As $\mathrm{T}_{\mathrm{g}}$ values of the powders determined (Table 4) are slightly higher than the storage temperature of $38^{\circ} \mathrm{C}$, and collapse or caking were not observed during storage time, it would be expected that systems maintained a glassy state and therefore high stability of their biocompounds.

The evolution of the color parameters was also studied during storage, in particular the red color that plays a vital role on the consumer election. Color parameter $\mathrm{a}^{*}$ is also shown on (Fig. 3a), considering the close relation existing between the TMA content and the redness color [49-65, 66]. Taking into account the particular differences of each fruit, $a^{*}$ values remained quite constant during the 60 days, following the same tendency as the degradation of TMA, behaving both parameters similarly in these freeze-dried products. Considering the corresponding data of $\mathrm{BB}, \mathrm{EB}$ and $\mathrm{BC}$ a high global correlation between parameter $\mathrm{a}^{*}$ and TMA content during storage was obtained, being $R=0.95(P<0.001, n=15)$.

As seen in (Fig. 3b) and considering the close relationship between the degradation of anthocyanins and color changes [67] the polymeric color (\% PC) was measured during storage, because its increase is usually associated with brownish tones. Graphically, the evolution of \% PC remains near to the initial value: in EB and BC it increases 11 and 19.5\% and decreases in BB and MB 5.54\% and 19\% respectively. These results would be aligned with the little variations in the parameter $\mathrm{a}^{*}$ observed during storage of freeze - dried powders. The initial values (BC 30\% PC, EB 42.81\% PC, BB 45.33\% PC and MB 51\% PC) are in the range reported in freeze dried berry products [68] and were lower than values obtained during storage of pasteurized berry juices found in previous studies [46].

The stability of TP was calculated after 60 days of storage, only in the blueberry there was a slight decrease of $19 \%$ with respect to the initial value $\left(\mathrm{TP}_{\mathrm{i}}: 2367.88-\mathrm{TP}_{\mathrm{f}}: 1911.75 \mathrm{GAE} \mathrm{mg} / \mathrm{l}\right.$ reconstituted juice) and in the rest of the fruits the TP content increased up to 1.48 times, being their values expressed as GAE $\mathrm{mg} / 1$ reconstituted juice: 1,48 $\left(\mathrm{TP}_{\mathrm{i}}: 4523.02-\mathrm{TP}_{\mathrm{f}}:\right.$ 6676.12) for $\mathrm{MB}, 1.43\left(\mathrm{TP}_{\mathrm{i}}: 3768.33-\mathrm{TP}_{\mathrm{f}}: 5387.46\right)$ for $\mathrm{EB}$ and $1.35\left(\mathrm{TP}_{\mathrm{i}}\right.$ : $\left.5098.50-\mathrm{TP}_{\mathrm{f}}: 6898.09\right)$ for $\mathrm{BC}$. 


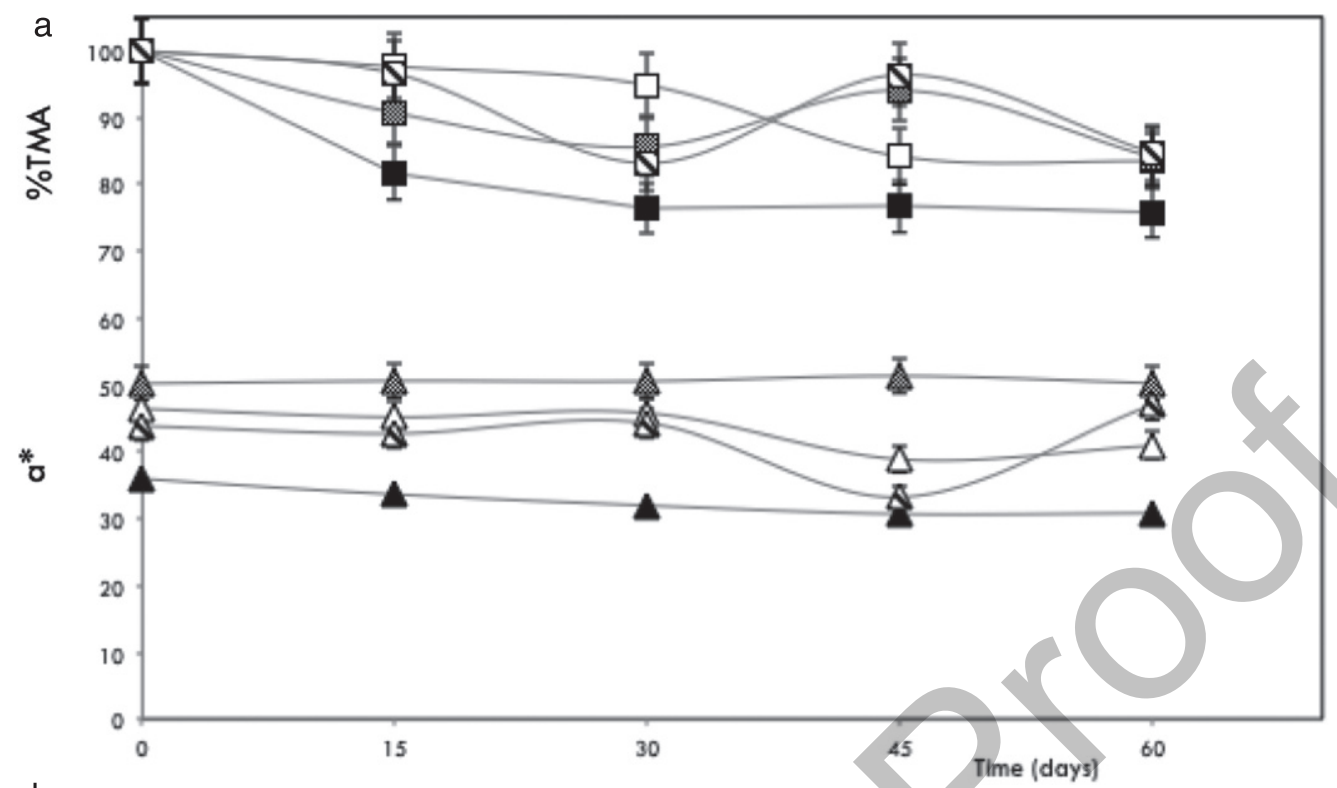

b

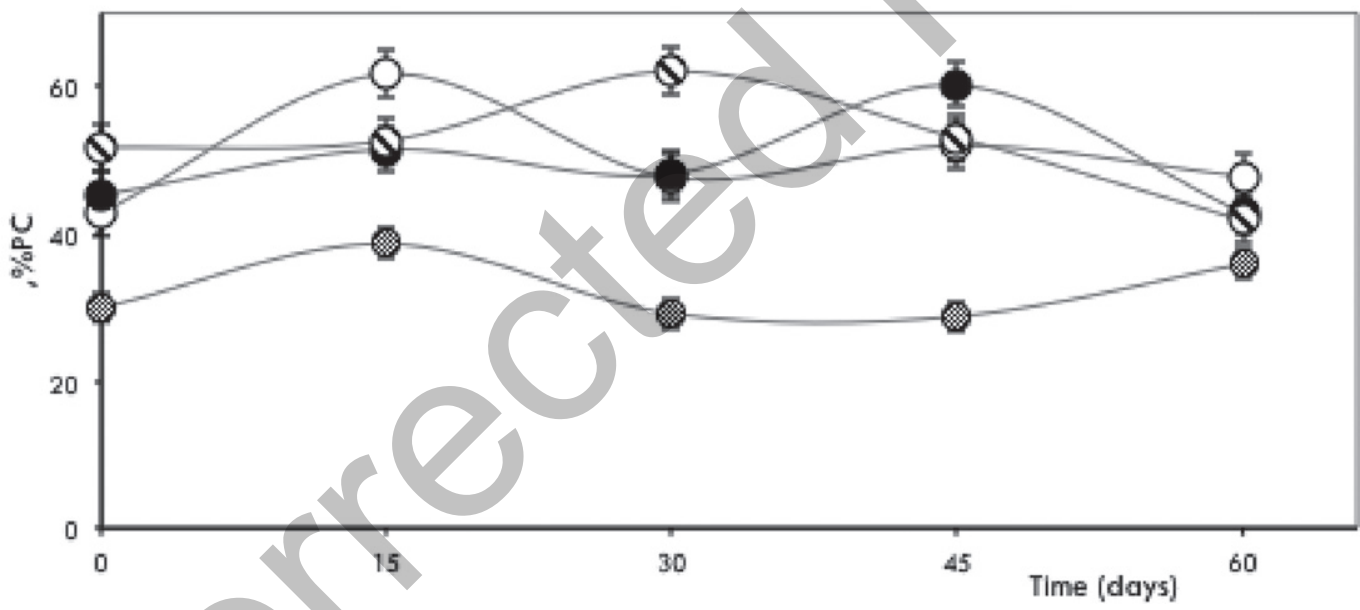

Fig. 3. (a) Comparison of total monomeric anthocyanins $\%$ retention ( $\%$ TMA $\square$ ) and a* (redness $\Delta$ ) color parameter of reconstituted freezedried powder of blueberry $(\mathbf{\square})$, elderberry $(\square)$, blackcurrant $(\square)$ and maqui berry $(\mathbf{\nabla})$ stored at $38^{\circ} \mathrm{C}$. Values are mean \pm standard error. (b) Comparison of percent polymeric color (\%PC $\bigcirc$ ) of reconstituted freeze-dried powder of blueberry $(\boldsymbol{\square})$, elderberry $(\square)$, blackcurrant ( $\square$ ) and maqui berry $(\mathbf{\nabla})$ stored at $38^{\circ} \mathrm{C}$. Values are mean \pm standard error.

Following the same tendency shown by anthocyanin content, antioxidant activity remained almost unchanged in the four powder systems, confirming the relationship existing between anthocyanin content and antioxidant activity in foods that contain these pigments [69]. The correspondent values, expressed as \% inhibition were: $\mathrm{TAC}_{\mathrm{i}}: 13.89 \%-\mathrm{TAC}_{\mathrm{f}}: 12.24 \%$ in BB; $\mathrm{TAC}_{\mathrm{i}}: 19.82 \%-\mathrm{TAC}_{\mathrm{f}}: 17.43 \%$ in $\mathrm{EB} ; \mathrm{TAC}_{\mathrm{i}}: 25.6 \%-\mathrm{TAC}_{\mathrm{f}}: 25.15 \%$ in $\mathrm{MB}$ and $\mathrm{TAC}_{\mathrm{i}}: 31.83 \%-\mathrm{TAC}_{\mathrm{f}}: 34.01 \%$ in $\mathrm{BC}$.

Flores and others [70] observed for spray-dried blueberry powder stored at $37^{\circ} \mathrm{C}$ during 35 days, that $\mathrm{TP}$ and TAC increased between 2 and 2.5. Moser et al [71] informed a small decrease in antioxidant activity, 

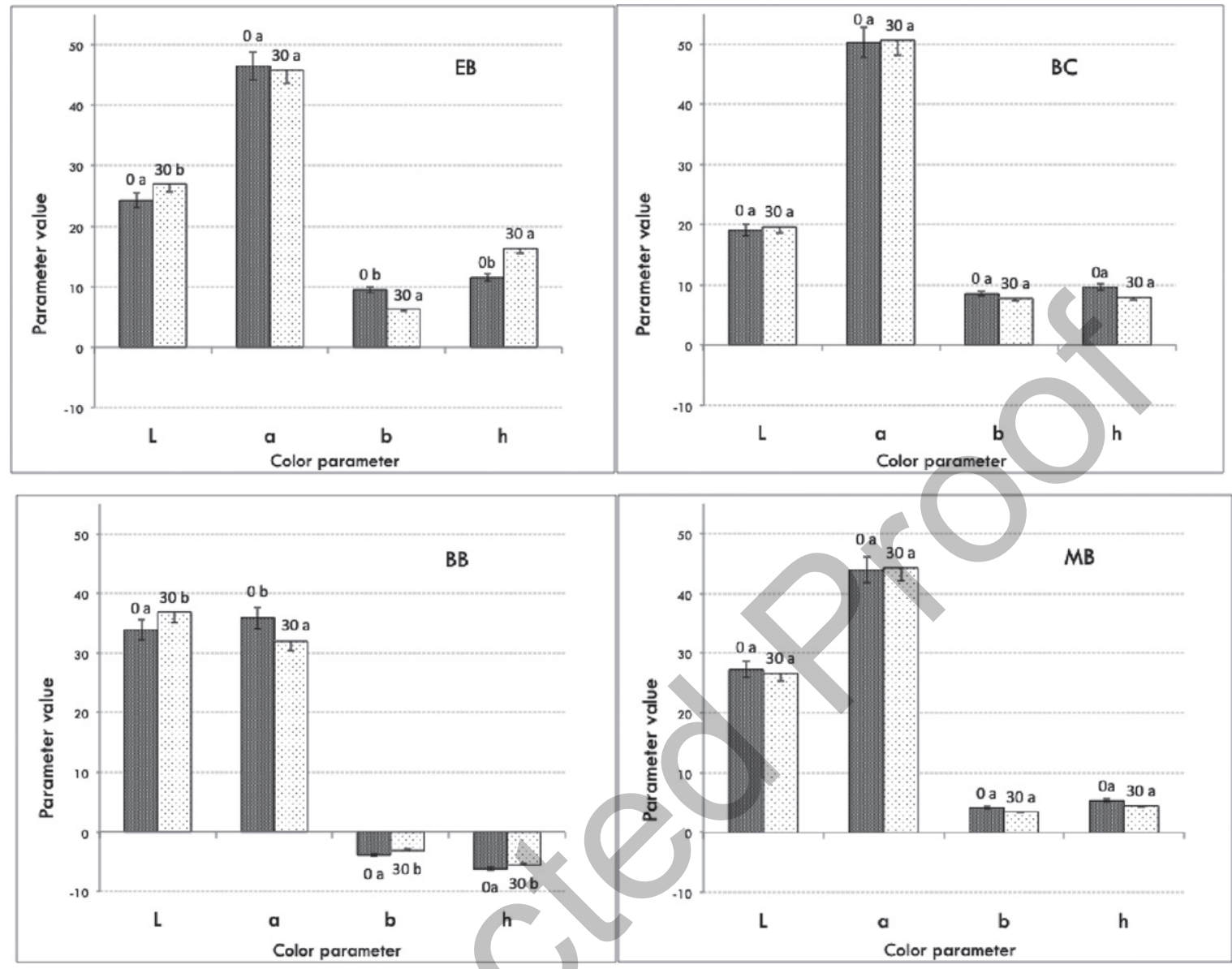

Fig. 4. Comparison of color parameters $\left(L^{*}, a^{*}, b^{*} h^{\circ}\right)$ for extracts of reconstituted freeze-dried powder of elderberry (EB), blackcurrant (BC), blueberry (BB), and maqui berry (MB) at 0 and 30 days stored at $38^{\circ} \mathrm{C}$. Different letters above the data bars indicate that color parameter differed between storage time, $P<0.05$. Values are mean \pm standard error, $n=8$.

between $6 \%-14 \%$ at the end of storage for grape microencapsulated powder with whey protein concentrate and maltodextrin. Rocha and team [72] reported that the antioxidant activity of freeze dried wine powder showed a good stability during 145 days at $38^{\circ} \mathrm{C}$ of accelerated storage, suggesting that despite having detected losses of certain phenolic compounds studied, they could be involved in the formation of new antioxidant compounds. Furthermore, the stability of the anthocyanin pigments extracted from acid cherries and stored with dextrins has been attributed to the complex formed between the flavylium cation of the anthocyanins and the dextrins that avoided their transformation into less stable structures [73].

Figure 4 shows the changes in CIELab parameters $\mathrm{a}^{*}, \mathrm{~b}^{*}, \mathrm{~L}^{*}$ and $\mathrm{h}^{\circ}$ in the alcoholic extracts of reconstituted powder, at initial time and after 30 days of storage at $38^{\circ} \mathrm{C}$. It should be noted that after 30 days no significant changes were observed in the color parameters. Samples based on elderberry and blueberry showed slight significant differences in all the parameters $(P<0.05)$, that were manifested in highest values obtained of the total color difference $\left(\Delta \mathrm{E}^{*}\right): 7.73 \pm 0.39$ for $\mathrm{EB} ; 6.23 \pm 0.31$ for $\mathrm{BB} ; 4.76 \pm 0.24$ for $\mathrm{BC}$; and $3.61 \pm 0.18$ for $\mathrm{MB}$. A minor proportion of juice solids encapsulated in EB and BB and their particular phenolic composition could contribute to produce more notorious changes during storage. Color and polyphenols stability are concordant 
with data found in literature for cherry, raspberry and Andes berry freeze-dried juices with addition of MD $[60,74,75]$.

\section{Conclusions}

The results obtained in present study allow to properly describe each powder system obtained from berry pulps and confirms their high levels of bioactive compounds, providing an important contribution to the knowledge of anthocyanin and polyphenols content and stability in fruits form Patagonian region of Argentina.

The powder systems obtained by freeze drying using $20 \%$ of encapsulating agents showed a high stability, associated with relatively high values of $\mathrm{T}_{\mathrm{g}}$ (range between $43-45^{\circ} \mathrm{C}$ ) and low values of $\mathrm{a}_{\mathrm{w}}$. The powders stored at $38^{\circ} \mathrm{C}$ showed very good retention of TMA (higher than $75 \%$ ) and for TP content only a $15 \%$ of decrease was seen in the case of blueberry meanwhile an increase was found for the rest. Stability was also observed in TAC. The high content of bioactive compounds in the powder samples makes them interesting for various applications as a functional ingredient for the development of food with benefits for human health industries and are the basis for future studies on this subject associated to the fruits of the region of Argentine Patagonia. Also, for the high color stability observed after freeze drying and storage, these dehydrated systems can be used as potential natural colorants in food or cosmetics industries, as ingredients of easy addition which can be stored at room temperature.

\section{Acknowledgments}

The authors would like to thank Michay Co S.A. (Río Negro, Argentina) for donating the commercial juices used in this study. The authors acknowledge the financial support from Pontificia Universidad Católica Argentina.

\section{Conflict of interest}

The authors have no conflict of interest to declare.

\section{References}

[1] Leal M, Guagliano ML, Sanchez Rico A. Estudio panorámico de vigilancia tecnológica e inteligencia competitiva: alimentos funcionales.1st ed. - Buenos Aires: Ministerio de Ciencia, Tecnología e Innovación Productiva 2016. Digitalbook, online ISBN 978-987-1632-64. Available from: www.mincyt.gob.ar

[2] Bigliardi B, Galati F. Innovation trends in the food industry: The case of functional foods. Trends in Food Science \& Technology. 2013;31(2):118-129. doi:10.1016/j.tifs.2013.03.006

[3] Prior RL, Sintara M, Chang T. Multi-radical (ORACMR5) antioxidant capacity of selected berries and effects of food processing. Journal of Berry Research. 2016;6(2):159-173. doi:10.3233/JBR-160127

[4] Sidor A, Gramza-Michałowska A. Advanced research on the antioxidant and health benefit of elderberry (Sambucus nigra) in food a review. Journal of functional foods. 2015;(18):941-958. doi:10.1016/j.jff.2014.07.012

[5] Kent K, Charlton K, Roodenrys S, Batterham M, Potter J, Traynor V, Gilbert H, Morgan O, Richards R. Consumption of anthocyaninrich cherry juice for 12 weeks improves memory and cognition in older adults with mild-to-moderate dementia. European Journal of Nutrition. 2017;56(1):333-341. doi:10.1007/s00394-015-1083-y

[6] Mueller D, Jung K, Winter M, Rogoll D, Melcher R, Richling E. Human intervention study to investigate the intestinal accessibility and bioavailability of anthocyanins from bilberries. Food Chemistry. 2017;231:275-286. doi:10.1016/j.foodchem.2017.03.130

[7] Liobikas J, Skemiene K, Trumbeckaite S, Borutaite V. Anthocyanins in cardioprotection: A path through mitochondria. Review article. Pharmacological Research. 2016;113:808-815. doi:10.1016/j.phrs.2016.03.036 
[8] Liu R. Dietary bioactive Compounds and Their Health Implications. Journal of Food Science. 2013;78:18-25. doi:10.1111/ 1750-3841.12101

[9] Nile SH, Park SW. Edible berries: Bioactive components and their effect on human. Nutrition. 2014;30:134-144. doi:10.1016/ j.nut.2013.04.007

[10] Gómez Riera P, Bruzone I, Kirschbaum DS. Visión prospectiva de la cadena de frutas finas al 2030.1 st ed.- Buenos Aires: Ministerio de Ciencia,Tecnología e Innovación Productiva, 2014. E-Book. ISBN 978-987-1632-38-1. Available from: www.mincyt.gob.ar

[11] Rein MJ. Copigmentation reactions and color stability of berry anthocyanins (dissertation). EKT series 1331. University of Helsinki, Department of Applied Chemistry and Microbiology. 2000; 88:34.

[12] Castañeda Ovando A, Pacheco-Hernández ML, Páez-Hernández MH, Rodríguez JA, Galán-Vidal CA. Chemical studies of anthocyanins: A review. Food Chemistry. 2009;113:859-871. doi:10.1016/j.foodchem.2008.09.001

[13] Kara Ş, Alben Erçelebi E. Thermal degradation kinetics of anthocyanins and visual colour of Urmu mulberry (Morus nigra L.). Journal of Food Engineering. 2013;116:541-547. doi:10.1016/j.jfoodeng.2012.12.030

[14] Brownmiller C, Howard IR, Prior RI. Processing and storage effects on monomeric anthocyanins, percent polymeric color, and antioxidant capacity of processed blueberry products. Journal of Food Science. 2008;73(5):72-79. doi:10.1111/j.1750-3841.2008.00761.x

[15] Franceschinis L, Salvatori MD, Sosa N, Schebor C. Physical and Functional Properties of Blackberry Freeze-and Spray-Dried Powders. Drying Technology. 2014;32:197-207. doi:10.1080/07373937.2013.814664

[16] Paz R, Fredes C. The encapsulation of Anthocyanins from Berry-type Fruits. Trends in Food Molecules. 2015;20:5875-5888. doi: $10.3390 /$ molecules20045875

[17] Moser P, Nicoletti V, Andrade Neves N, García-Romero E, Gómez-Alonso S, Hermosín-Gutiérrez I. Storage stability of phenolic compounds in powdered BRS Violeta grape juice microencapsulated with protein and maltodextrin blends. Food Chemistry. 2017;214:308-318. doi:10.1016/j.foodchem.2016.07.081

[18] Nemzera B, Vargasb L, Xiaa X, Sintarac M, Feng H. Phytochemical and physical properties of blueberries, tart cherries, strawberries, and cranberries as affected by different drying methods. Food Chemistry. 2018;262:242-250. doi:10.1016/j.foodchem.2018.04.047

[19] Samoticha J, Wojdyło A, Lech X. The influence of different the drying methods on chemical composition and antioxidant activity in chokeberries. LWT - Food Science and Technology. 2016;66:484-489. doi:10.1016/j.lwt.2015.10.073

[20] Yamashita C, Song Chung M, Dos Santos C, Malacrida Mayer R, Freitas Moraes I Branco I. Microencapsulation of an anthocyaninrich blackberry (Rubus spp.) by-product extract by freeze-drying. LWT - Food Science and Technology. 2017;84:256-262. doi:10.1016/j.1wt.2017.05.063

[21] Ray S, Raychaudhuri U, Chakraborty R. An overview of encapsulation of active compounds used in food products by drying technology. Food Bioscience. 2016;13:76-83. doi:10.1016/j.fbio.2015.12.009

[22] Salamon I, Grulova D, Hancianu M, Cioanca O. Optimization of Lyophilization Technology for Purification and Stabilization of Anthocyanins from Elderberry Fruits. Acta horticulturae. 2015;1061:245-252. doi:10.17660/ActaHortic.2015.1061.27

[23] Siede Kuck L, Zapata Noreña CP. Microencapsulation of grape (Vitis labrusca var. Bordo) skin phenolic extract using gum Arabic, polydextrose, and partially hydrolyzed guargum as encapsulating agents. Food Chemistry. 2016;194:569-576. doi:10.1016/j.foodchem.2015.08.066

[24] Agudelo C, Barros L, Santos-Buelga C, Martinez Navarrete N, Ferreira I. Phytochemical content and antioxidant activity of grapefruit (Star Ruby): A comparison between fresh freeze-dried fruits and different powder formulations. LWT - Food Science and Technology. 2017;80:106-112. doi:10.1016/j.1wt.2017.02.006

[25] Murali S, Kar A, Mohapatra D, Kalia P. Encapsulation of black carrot juice using spray and freeze-drying. Food Sci Technol Int. 2014;21(8):604-12. doi:10.1177/1082013214557843

[26] Saikia S, Mahnot NK, Mahanta CL. Optimization of phenolic extraction from Averrhocarambola pomace by response surface methodology and its microencapsulation by spray and freeze drying. Food Chemistry. 2015;171:144-152. doi:10.1016/ j.foodchem.2014.08.064

[27] Labuza, T.P. and Schmidl, MK. Accelerated shelf life testing of foods. Food Technology. 1985;39(9):57-62.

[28] Franceschinis L, Sosa N, Schebor C, Salvatori DM. Changes in color and the anthocyanin content of different dried products based on sweet cherries. Proc AIC 2010 Color and Food, Interim Meeting of the International Color Asociation. 2010

[29] Favetto GJ, Resnik SL, Chirife J, Ferro Fontán C. Statistical evaluation of water activity measurements obtained with the Vaisala Humicap humidity meter. Journal of Food Science. 1983;487:534-538. doi:10.1111/j.1365-2621.1983.tb10783.x

[30] Waterhouse AL. Determination of Total Phenolics. Current Protocols in Food Analytical Chemistry; I1.1.1-I1.1.8. Wrolstad, R.E., Wiley ed. 2001.

[31] Giusti MM, Wrolstad RE. Characterization and measurement of anthocyanins by UV-visible spectroscopy. Current Protocols in Food Analytical Chemistry 1st ed. John Wiley and Sons, Inc; 2001.p F1.2.1-F1.2.13.

[32] Michalczyk M, Ryszard M, Matuszak I. The effect of air-drying, freeze-drying and storage on the quality and antioxidant activity of some selected berries. Journal of Food Processing and Preservation. 2009;33:11-21. doi:10.1111/j.1745-4549.2008.00232.x 
[33] Hager TJ, Howard LR, Liyanage R, Lay JO, Prior RL. Ellagitannin composition of blackberry as determined by HPLC-ESI-MS and MALDI-TOF-MS. Journal of Agricultural and Food Chemistry. 2008;56:661-69. doi:10.1021/jf071990b

[34] Brand-Williams W, Cuvelier ME, Berset C. Use of free radical method to evaluate antioxidant activity. Lebensm-Wiss.u-Technology. 1995;28:25-30. doi:10.1016/S0023-6438(95)80008-5

[35] Evelson P, Travacio M, Repetto M, Escobar J, Llesuy S, Lissi E. Evaluation of total reactive antioxidant potential (TRAP) of tissue homogenates and their cytosols. Arch. Biochem. Biophys. 2001;388:261-266. doi:10.1006/abbi.2001.2292

[36] Di Rienzo JA, Casanoves F, Balzarini MG, Gonzalez L, Tablada M, Robledo CW. InfoStat versión 2017. Grupo InfoStat, FCA, Universidad Nacional de Córdoba, Argentina. URL Avialable from: www.infostat.com.ar

[37] Pino Pinto CM.Descripción del desarrollo vegetativo y de las características físicas y químicas de los frutos de cuatro clones de arándano alto (Vaccinium corymbosum L.). Escuela de Agronomía. Universidad Austral de Chile. 2007. Availble from: www.cybertesis.uach.cl

[38] Siksnianas T, Stanys V, Sasnauskas A,Viskelis P, Rubinskiene M. Fruit quality and Processing potential in five new blackcurrant cultivars. Journal of fruit and ornamental plant research. 2006;14:265-271.

[39] Lee J, Finn Ch. Anthocyanins and other polyphenolics in American elderberry (Sambucus canadensis) and European elderberry (S. nigra) cultivars. J Sci Food Agric. 2007;87:2665-2675. doi:10.1002/jsfa.3029

[40] Araneda X, Quilamán E, Martínez M, Morales D. Elaboración y evaluación de jugo de maqui (Aristotelia chilensis (Mol.) Stuntz) por arrastre de vapor. Scientia Agropecuaria. 2014;5:149-156.

[41] Skupien K. Chemical composition of selected cultivars of highbush blueberry fruit (Vaccinium corymbosum L.). Folia Horticulturae Ann. 2006;18:47-56.

[42] Fredes C, Montenegro G, Zoffoli JP, Gómez M, Robert P. Polyphenol content and antioxidant activity of maqui (aristotelia chilensis [MOLINA] STUNTZ) during fruit development and maturation in central Chile. Chilean Journal of Agricultural Research. 2012;72(4):582-589. doi:10.4067/S0718-58392012000400019

[43] Vulic JJ, Vraçar LO, Şumić ZM. Chemical characteristics of cultivated elderberry fruit. Acta Periodica Technologica. 2008;39:85-90. doi:10.2298/APT0839085V

[44] Sadilova E, Stintzing FC, Kammere DR. Reinhold C. Matrix dependent impact of sugar and ascorbic acid addition on color and anthocyanin stability of black carrot, elderberry and strawberry single strength and from concentrate juices upon thermal treatment. Food Research International. 2009;42:1023-1033. doi:10.1016/j.foodres.2009.04.008

[45] Swaminathan S, Sowriappan J, Sneha F, Mallela S. Effect of inlet temperature on physicochemical properties of spray-dried jamun fruit juice powder. Powder Technology. 2015;274:37-43. doi:10.1016/j.powtec.2015.01.016

[46] Busso Casati C, Baeza R, Sanchez V, Catalano A, Lopez P, Zamora MC. Thermal degradation kinetics of monomeric anthocyanins, colour changes and storage effect in elderberry juices. Journal of Berry Research. 2015;5:29-39. doi:10.3233/JBR-150088

[47] Kevers C, Pincemail J, Defraigne JO, Dommes J. Antioxidant capacity of small dark fruits: Influence of cultivars and harvest time. Journal of Berry Research. 2014;4:97-105. doi:10.3233/JBR-140071

[48] Jakobek L, Seruga M, Medvidovic-Kosanovic M, Novak I. Anthocyacnin content and antioxidant activity of various red fruits juices. Deutsche Lebensmittel-Rundschau. 2007;103(2):58-64.

[49] Busso Casati C, Sanchez V, Baeza R, Magnani N, Evelson P, Zamora. MC. Relationships between colour parameters, phenolic content and sensory changes of processed blueberry, elderberry and blackcurrant commercial juices. International Journal of Food Science and Technology. 2012;47:1728-1736. doi:10.1016/j.foodchem.2012.10.072

[50] Konic-Ristic A, Šavikin K, Zdunic G, Jankovic T, Juranic Z, Menkovic N, Stankovic I. Biological activity and chemical composition of different berry juices. Food Chemistry. 2011;125:1412-1417. doi:10.1016/j.foodchem.2010.10.018

[51] Viskeli P, Bobinaite R, Rubinskiene M, Sasnauskas A, Lanauskas J.Chemical Composition and Antioxidant Activity of Small Fruits, Horticulture. 2012; Prof. Alejandro Isabel Luna Maldonado Ed., ISBN: 978-953-51-0252-6, InTech, Available: www.intechopen.com

[52] Fredes C, Montenegro G, Zoffoli JP, Santander F, Robert P. Comparison of the total phenolic content, total anthocyanin content and antioxidant activity of polyphenol -rich fruits grown in Chile. Cien.Inv.Agr. 2014;41(1):49-60. doi:10.7764/rcia.v41i1.1224

[53] Brauch JE, Buchweitz M, Schweiggert M, Carle R. Detailed analyses of fresh and dried maqui (Aristotelia chilensis (Mol.) Stuntz) berries and juice. Food Chemistry. 2016;190:308-316. doi:10.1016/j.foodchem.2015.05.097

[54] Muller L, Gnoyke S, Popken AM, Bohma,V. Antioxidant capacity and related parameters of different fruit formulations. LWT - Food Science and Technology. 2010, 43:992-999. doi:10.1016/j.lwt.2010.02.004

[55] Reque PM, Steffens RS, Jablonski A, Flôres SH, Rios AO, Jong EV. Cold storage of blueberry (Vaccinium spp.) fruits and juice: Anthocyanin stability and antioxidant activity. Journal of Food Composition and Analysis. 2014;33:111-116. doi:10.1016/j.jfca.2013.11.007

[56] Lasagni Vitar RM, Reides CG, Ferreira SM, Llesuy SF. The protective effect of Aloysia triphylla aqueous extracts against brain lipid-peroxidation. Food \& Function. 2014;5:557-563. doi:10.1039/C3FO60392J

[57] Cheng AW, Xia Xie H, Qi Y, Liu Ch, Guo X, Sun J, Liu LN. Effects of storage time and temperature on polyphenolic content and qualitative characteristics of freeze-dried and spray-dried bayberry powder. LWT - Food Science and Technology. 2017;78:235-240. doi:10.1016/j.lwt.2016.12.027 
[58] Sette P, Franceschinis L, Schebor C, Salvatori, D. Fruit snacks from raspberries: influence of drying parameters on colour degradation and bioactive potential. International Journal of Food Science and Technology. 2017;52:313-328. doi:10.1111/ijfs.13283

[59] Can Karaca A, Guzel O, Ak MM. Effects of processing conditions and formulation on spray drying of sour cherry juice concentrate. Journal of the Science of Food and Agriculture. 2016;96:449-455. doi:10.1002/jsfa.7110

[60] Sanchez V, Baeza R, Chirife J. Comparison of monomeric anthocyanins and colour stability of fresh, concentrate and freeze-dried encapsulated cherry juice stored at $38^{\circ}$ C. Journal of Berry Research. 2015;5:243-251. doi:10.3222/JBR-150106

[61] Fang Z, Bhandari B. Comparing the efficiency of protein and maltodextrin on spray drying of bayberry juice. Food Research International. 2012;48:478-483. doi:10.1016/j.foodres.2012.05.025

[62] Otálora MC, Carriazo JG, Iturriaga L, Nazareno MA, Osorio C. Microencapsulation of betalains obtained from cactus fruit (Opuntia ficus-indica) by spray drying using cactus cladode mucilage and maltodextrin as encapsulating agents. Food Chem. 2015;187:174-81. doi:10.1016/j.foodchem.2015.04.090

[63] Colato Antonio G, Faria FR, Takeiti CY, Park KJ. Rheological behavior of blueberry. Ciênc. Tecnol. Aliment. 2009;29(4):732-737. doi:10.1590/S0101-20612009000400006

[64] Garzón GA, Worlstad RG. The stability of pelargonidin based anthocyanins at varying water activity. Food Chemistry. 2001;75:185196. doi:10.1016/S0308-8146(01)00196-0

[65] Schmitzer V, Osterc G, Veberic R, Stampar F. Correlation between chromaticity values and major anthocyanins in seven Acer palmatum Thunb. Cultivars. Scientia Horticulturae. 2009;119:442-446. doi:10.1016/j.scienta.2008.09.003

[66] Fischer U, Carle R, Kammerer DR. Thermal stability of anthocyanins and colourless phenolics in pomegranate (Punica granatum L.) juices and model solutions. Food Chemistry. 2013;138:1800-1809. doi:10.1016/j.foodchem.2012.10.072

[67] Presilski S, Presilska N, Tomovska D. Effects of Extraction, Conventional Processing and Storage on Natural Anthocyanins. J Food Process Technol. 2016;7:551. doi:10.4172/2157-7110.1000551

[68] Howard LK, Prior RL, Liyanage R, O.Lay J. Processing and Storage Effect on Berry Polyphenols: Challenges and Implications for Bioactive Properties. J.Agric.Food.Chem. 2012;60:6678-6693. doi:10.1021/jf2046575

[69] Tonon RV, Brabet C, Hubinger MD. Anthocyanin stability and antioxidant activity of spray-dried açai (Euterpe oleracea Mart.) juice produced with different carrier agents. Food Research International. 2010;43:907-914. doi:10.1016/j.foodres.2009.12.013

[70] Flores FP, Singh RK, Kong F. Physical and storage properties of spray-dried blueberry pomace extract with whey protein isolate as wall material. Journal of Food Engineering. 2014;137:1-6. doi:10.1016/j.jfoodeng.2014.03.034

[71] Moser P, Nicoletti Telis VR, De Andrade Neves N, García-Romero E, Gómez-Alonso S, Hermosín-Gutiérrez I. Storage stability of phenolic compounds in powdered BRS Violeta grape juice microencapsulated with protein and maltodextrin blends. Food Chemistry. 2017;214:308-318. doi:10.1016/j.foodchem.2016.07.081

[72] Rocha-Parra DF, Lanari MC, Zamora MC, Chirife J. Influence of storage conditions on phenolic compounds stability, antioxidant capacity and colour of freeze-dried encapsulated red wine. LWT - Food Science and Technology. 2016;70:162-170. doi:10.1016/j.1wt.2016.02.038

[73] Chandra A, Nair M, Iezzoni A. Isolation and stabilization of anthocyanins from tart cherries (Prunus cerasus L.). Journal of Agricultural and Food Chemistry. 1993;41(7):1062-1065. doi:10.1021/jf00031a009

[74] Laine P, Kylli P, Heinonen M, Jouppila K. Storage stability of microencapsulated cloudberry (Rubus chamaemorus) phenolics. Journal of Agriculture and Food Chemistry. 2008;56(23):11251. doi:10.1021/jf801868h

[75] Estupiñan DC, Schwartz SJ, Garzón GA. Antioxidant activity, total phenolics content, anthocyanin, and color stability of isotonic model beverages colored with Andes berry (Rubus glaucus Benth) anthocyanin powder. Journal of Food Science. 2011;76(1):10111. doi:10.1111/j.1750-3841.2010.01935.x 